\title{
Carvedilol Induces Endogenous Hydrogen Sulfide Tissue Concentration Changes in Various Mouse Organs*
}

\author{
Bogdan WiLIŃSKI, Jerzy WILIŃSKI, Eugeniusz SOMOGYI, Joanna PIOTROWSKA, \\ Marta GÓRALSKA, and Barbara MACURA
}

Accepted May 19, 2011

\begin{abstract}
Wiliński B., Wiliński J., SOMOgyi E., Piotrowska J., Góralska M., Macura B. 2011. Carvedilol induces endogenous hydrogen sulfide tissue concentration changes in various mouse organs. Folia biologica (Kraków) 59: 151-155.

Carvedilol, a third generation non-selective adrenoreceptor blocker, is widely used in cardiology. Its action has been proven to reach beyond adrenergic antagonism and involves multiple biological mechanisms. The interaction between carvedilol and endogenous 'gasotransmitter' hydrogen sulfide $\left(\mathrm{H}_{2} \mathrm{~S}\right)$ is unknown. The aim of the study is to assess the influence of carvedilol on the $\mathrm{H}_{2} \mathrm{~S}$ tissue level in mouse brain, liver, heart and kidney. Twenty eight SJL strain female mice were administered intraperitoneal injections of $2.5 \mathrm{mg} / \mathrm{kg}$ b.w./d (group D1, $\mathrm{n}=7$ ), $5 \mathrm{mg} / \mathrm{kg} \mathrm{b} . \mathrm{w} . / \mathrm{d}$ (group D2, $\mathrm{n}=7$ ) or $10 \mathrm{mg} / \mathrm{kg} \mathrm{b} . \mathrm{w} . / \mathrm{d}$ of carvedilol (group D3, $n=7)$. The control group $(n=7)$ received physiological saline in portions of the same volume $(0.2 \mathrm{ml})$. Measurements of the free tissue $\mathrm{H}_{2} \mathrm{~S}$ concentrations were performed according to the modified method of Siegel. A progressive decline in $\mathrm{H}_{2} \mathrm{~S}$ tissue concentration along with an increase in carvedilol dose was observed in the brain $(12.5 \%$, $13.7 \%$ and $19.6 \%$, respectively). Only the highest carvedilol dose induced a change in $\mathrm{H}_{2} \mathrm{~S}$ tissue level in the heart - an increase by $75.5 \%$. In the liver medium and high doses of carvedilol increased the $\mathrm{H}_{2} \mathrm{~S}$ level by $48.1 \%$ and $11.8 \%$, respectively. In the kidney, group D2 showed a significant decrease of $\mathrm{H}_{2} \mathrm{~S}$ tissue level $(22.5 \%)$, while in the D3 group the $\mathrm{H}_{2} \mathrm{~S}$ concentration increased by $12.9 \%$. Our study has proven that carvedilol affects $\mathrm{H}_{2} \mathrm{~S}$ tissue concentration in different mouse organs.
\end{abstract}

Key words: Hydrogen sulfide, carvedilol, adrenergic beta-antagonists, nitric oxide, mice.

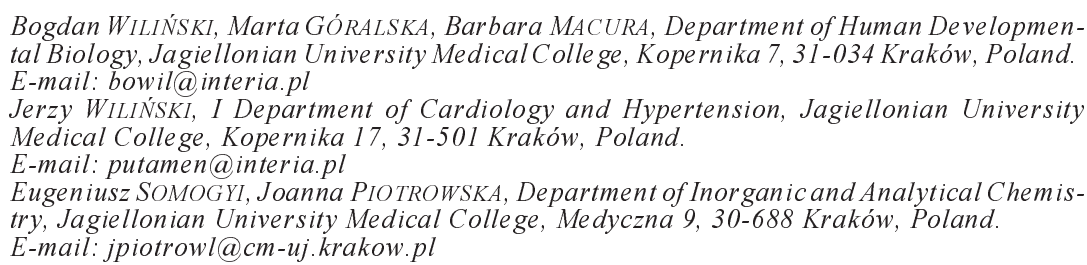

Carvedilol, a third generation non-selective adrenoreceptor blocker, is widely used in cardiology and general practice in the treatment of chronic diseases like congestive heart failure and arterial hypertension (CHAKRABORTY et al. 2010). The action of carvedilol has been proven to reach beyond adrenergic antagonism and comprises i.a. antioxidant activity, calcium channel blockade and nitric oxide (NO) production enhancement (KOSTKA-JEZIERNY \& TYKARSKI 2009). On the other hand, endogenously formed 'gasotransmitter' hydrogen sulfide $\left(\mathrm{H}_{2} \mathrm{~S}\right)$ has been identified as a crucial regulator of circulatory, nervous, gastrointestinal and excretory systems. Altered production of $\mathrm{H}_{2} \mathrm{~S}$ was observed in arterial hypertension, myocardial ische- mia and atherosclerosis (ŁOWICKA \& BEŁTOWSKI 2007). The interaction between carvedilol and endogenous $\mathrm{H}_{2} \mathrm{~S}$ is unknown.

The aim of the study is to assess the influence of carvedilol on the endogenous tissue $\mathrm{H}_{2} \mathrm{~S}$ concentrations in mouse brain, heart, liver and kidney.

\section{Material and Methods}

\section{Animals}

Twenty eight SJL strain female mice (11-12 week old individuals) of approximately $20 \mathrm{~g}$ weight were involved in the study. The animals were housed under standard laboratory conditions and had free 
access to water and food. They were kept at a temperature of $22-24^{\circ} \mathrm{C}$ with a light/dark cycle of $12 \mathrm{~h}$.

\section{Study protocol}

A non-selective lipophilic $\beta$-blocker $/ \alpha$ - 1 blocker carvedilol (Avedol, Polpharma, Poland) was dissolved in physiological saline. The study design comprised intraperitoneal injections of $2.5 \mathrm{mg}$ per $\mathrm{kg}$ of body weight of carvedilol daily (group D1, n=7), $5 \mathrm{mg}$ per $\mathrm{kg}$ of body weight of carvedilol daily (group D2, n =7) or $10 \mathrm{mg}$ per $\mathrm{kg}$ of body weight of carvedilol daily (group D3, $\mathrm{n}=7$ ) for 5 consecutive days at the same time of day (10:30 am), each administration consisted of $0.2 \mathrm{ml}$ of the solution. The control population $(n=7)$ received intraperitoneally physiological saline in portions of the same volume. The individuals were randomly assigned to each group. The animals tolerated the applied doses of carvedilol well and remained in good condition till the end of the experiment. Measurements of the free tissue $\mathrm{H}_{2} \mathrm{~S}$ concentration were performed by the use of the modified method of Siegel (SiEgel 1965; SOMOGYI et al. 2008). The study has been performed in accordance with the guidelines for the care and use of laboratory animals accepted by Bioethical Committee of the Jagiellonian University Medical College (Kraków, Poland).

\section{Tissue sample preparation}

Two hours after the last drug or physiological saline injection the animals were killed by cervical dislocation, their brains, hearts, livers and kidneys were quickly removed, homogenized with $0.01 \mathrm{~mol} / 1$ sodium hydroxide $(\mathrm{NaOH})$ : brain tissue in proportion of 1 to 4, liver and kidney of 1 to 5 and heart of 1 to 10 and frozen. Then $50 \%$ trichloroacetic acid (TCA) was added $(0.5 \mathrm{ml}$ to $2 \mathrm{~g}$ of brain or liver samples in tight capsules of $3 \mathrm{ml}$ and $0.25 \mathrm{ml}$ to $1 \mathrm{~g}$ of heart or kidney sample in tight capsules of $2 \mathrm{ml}$ ), the suspension was shaken and centrifuged. Subsequently, $1.5 \mathrm{ml}$ brain or liver and $0.75 \mathrm{ml}$ heart or kidney supernatant samples were moved to $2 \mathrm{ml}$ tight capsules with $0.15 \mathrm{ml}$ or $0.075 \mathrm{ml}$ of $0.02 \mathrm{~mol} / 1$ $\mathrm{N}, \mathrm{N}$-dimethyl-p-phenyl-diamine sulfate in $7.2 \mathrm{~mol} / \mathrm{l}$ hydrochloric acid $(\mathrm{HCl})$, then $0.15 \mathrm{ml}$ or $0.075 \mathrm{ml}$ of $0.03 \mathrm{~mol} / 1$ iron (III) chloride $\left(\mathrm{FeCl}_{3}\right)$ in $1.2 \mathrm{~mol} / 1$ $\mathrm{HCl}$ portions were added, respectively. After 20 minutes in darkness the content was shaken for 1 minute with $1 \mathrm{ml}$ of chloroform.

\section{$\mathrm{H}_{2} \mathrm{~S}$ tissue concentration measurements}

Absorbance was measured at $650 \mathrm{~nm}$ with the Varian Cary 100 spectrophotometer. A standard curve was prepared with an iodometrically determined
$0.0001 \mathrm{~mol} / \mathrm{l}$ sodium sulfide $\left(\mathrm{Na}_{2} \mathrm{~S}\right)$ solution. For each group of animals four concurrent analyses of each analyzed tissue type were performed.

\section{Statistical analysis}

Statistical analysis was performed within the $\mathrm{R}$ Environment by the Student's $t$-test and univariate analysis of variance (ANOVA). Statistical significance was considered when $\mathrm{P}<0.05$.

\section{Results and Discussion}

Progressive $\mathrm{H}_{2} \mathrm{~S}$ tissue concentration decline was observed in the brain along with a rising carvedilol dose (by $12.5 \%, 13.7 \%$ and $19.6 \%$, respectively). In the heart only the highest carvedilol dose induced $\mathrm{H}_{2} \mathrm{~S}$ tissue level change, but the increase was spectacular, reaching $75.5 \%$. In the liver, medium and high doses altered the $\mathrm{H}_{2} \mathrm{~S}$ concentration $-5 \mathrm{mg} / \mathrm{kg}$ b.w./d of carvedilol increased the $\mathrm{H}_{2} \mathrm{~S}$ level by $48.1 \%$ and $10 \mathrm{mg} / \mathrm{kg}$ b.w/d by $11.8 \%$. In the kidney, the group D2 showed a significant decrease of $\mathrm{H}_{2} \mathrm{~S}$ tissue level (22.5\%), while in the D3 group $\mathrm{H}_{2} \mathrm{~S}$ concentration increased by $12.9 \%$. In the variance analysis for each tissue type only $\mathrm{H}_{2} \mathrm{~S}$ concentration changes within the heart and brain were statistically significant (Table 1). Noteworthy, each organ has different metabolism, paracrine and endocrine regulation, and specific transmitter interactions, thus variable changes of $\mathrm{H}_{2} \mathrm{~S}$ concentrations only confirm this complexity and heterogeneity.

Carvedilol's therapeutic actions could not be fully explained by adrenoreceptor blockade. Numerous studies have provided evidence that carvedilol has various other properties including antioxidant action, calcium channel antagonism, anti-inflammatory actions: fall in interleukin-1 (IL-1), interleukin-6 (IL-6), c-reactive protein (CRP) and tumor necrosis factor- $\alpha$ (TNF- $\alpha$ ), direct inhibition of transcription factors like NF- $\mathrm{kB}$, low density lipoproteins (LDL) oxidation; stabilization of atherosclerotic plaques by decreasing intercellular adhesion molecule-1 (ICAM-1) and activity of matrix metalloproteinases 2 and 9 (MMP-2, MMP-9); prevention of endothelial and myocardium apoptosis, reversal of cardiac remodeling in chronic heart failure and endothelin-1 (ET-1) suppression (BELLENGER et al. 2004; KALINOWSKI et al. 2003; KOSTKA-JEZIERNY \& TYKARSKI 2009; ROMEO et al. 2000; RUFFOLO et al. 1993). Moreover, the major proportion of carvedilol's biological action, especially regarding hypotensive and vascular effects, seems to be mediated by NO, whose level rises due to endothelial nitric oxide synthase (NOS) stimulation (AFONSO et al. 2006). 
Table 1

Hydrogen sulfide $\left(\mathrm{H}_{2} \mathrm{~S}\right)$ tissue concentration in mouse brain, heart, liver and kidney following the administration of $2.5 \mathrm{mg} / \mathrm{kg}$ b.w. per day, $5 \mathrm{mg} / \mathrm{kg} \mathrm{b}$.w. per day or $10 \mathrm{mg} / \mathrm{kg}$ b.w. per day of carvedilol (groups D1, D2 and D3 respectively)

\begin{tabular}{|l|c|c|c|c|c|}
\hline \begin{tabular}{|l|c|c|c|}
$\mathrm{H}_{2} \mathrm{~S}$ tissue concentration \\
$(\mu \mathrm{g} / \mathrm{g})$
\end{tabular} & $\begin{array}{c}\text { Control group } \\
(\mathrm{n}=7)\end{array}$ & $\begin{array}{c}\mathrm{D} 1 \\
(\mathrm{n}=7)\end{array}$ & $\begin{array}{c}\mathrm{D} 2 \\
(\mathrm{n}=7)\end{array}$ & $\begin{array}{c}\mathrm{D} 3 \\
(\mathrm{n}=7)\end{array}$ & $\begin{array}{c}\text { ANOVA } \\
\mathrm{P}\end{array}$ \\
\hline Brain & $2.55 \pm 0.04$ & $2.23 \pm 0.05^{* *}$ & $2.20 \pm 0.05^{* *}$ & $2.05 \pm 0.05^{* * *}$ & $<0.001$ \\
\hline Heart & $6.78 \pm 0.06$ & $5.91 \pm 0.15$ & $6.61 \pm 0.14$ & $11.90 \pm 0.12^{* * *}$ & $<0.001$ \\
\hline Liver & $4.14 \pm 0.04$ & $4.17 \pm 0.08$ & $6.13 \pm 0.14^{* * *}$ & $4.63 \pm 0.10^{* *}$ & 0.22 \\
\hline Kidney & $8.66 \pm 0.19$ & $8.45 \pm 0.17$ & $6.71 \pm 0.08^{* * *}$ & $9.78 \pm 0.18^{* * *}$ & 0.21 \\
\hline
\end{tabular}

$* \mathrm{P}<0.05$ for given group vs control group, ${ }^{*} * \mathrm{P}<0.01$ for given group vs control group, ${ }^{*} * \mathrm{P}<0.001$ for given group vs control group

$\mathrm{H}_{2} \mathrm{~S}$ is endogenously formed from L-cysteine in several enzymatic reactions catalyzed by cystathionine $\beta$-synthase (CBS), cystathionine $\gamma$-lyase (CSE) and 3-mercaptopyruvate sulfurtransferase (3MST), and in non-enzymatic pathways in many tissues. Cytoplasmatic bound sulfur is postulated to absorb and store exogenously applied and endogenously produced $\mathrm{H}_{2} \mathrm{~S}$ which is released from the bound sulfur pool in the presence of physiologic concentrations of glutathione and cysteine in slightly alkaline conditions (ISHIGAMI et al. 2009). $\mathrm{H}_{2} \mathrm{~S}$ acts as a 'gasotransmitter' and serves as a co-modulator of various physiological and pathophysiological processes such as regulation of vascular tone, myocardial contractility, neurotransmission and perception (FIORUCCI et al. 2006; SHIBUYA et al. 2009). Its biological action comprises numerous intracellular mechanisms including adenosine triphosphate (ATP)-sensitive potassium channels $\left(\mathrm{K}_{\mathrm{ATP}}\right)$ stimulation, sulfhydration of different proteins and maintaining protein-SH groups in the reduced state, reaction with reactive oxygen and nitrogen species (ROS and RNS) (ŁOWICKA \& BEŁTOWSKI 2007; SUN et al. 2008). $\mathrm{H}_{2} \mathrm{~S}$ interacts with carbon monoxide $(\mathrm{CO})$ and nitric oxide $(\mathrm{NO})$ in a number of ways including affecting each other's synthesis and biological responses within target tissues. All these three gases bind to haemoglobin and impede mitochondrial oxidative phosphorylation by inhibiting cytochrome c oxidase (LI et al. 2009). Analogically to carvedilol, $\mathrm{H}_{2} \mathrm{~S}$ decreases IL-6, TNF- $\alpha$ levels, reduces the activation of NF- $\mathrm{\kappa B}$ complex and the activity of MMP-2 and MMP-9 (OH et al. 2006; SEN et al. 2009; SODHA et al. 2009).
Our study has shown that carvedilol's action involves $\mathrm{H}_{2} \mathrm{~S}$, probably via its production rate alteration and release with possible NO share as one of the mechanisms. Some of the biological effects of the beta-blocker and $\mathrm{H}_{2} \mathrm{~S}$ are common. It is unknown whether $\mathrm{H}_{2} \mathrm{~S}$ mediates any of them and to what extent carvedilol's biology is dependent on the messenger, since research dedicated to the issue has not been done. In the heart, the cardioprotective effects of $\mathrm{H}_{2} \mathrm{~S}$ have been demonstrated to involve opening of $\mathrm{K}_{\mathrm{ATP}}$ channels as well as effects of preserving mitochondrial structure and function (ELROD et al. 2007). It might be an accessory effect to NO beneficial impact on intracellular transcription factors resulting in increased expression of cardioprotective proteins like superoxide dismutase (SOD), inducible NOS (iNOS), cyclooxygenase-2 (COX-2) and heat shock proteins (DAWN \& BOLLI 2002). In hepatology, carvedilol appears to be a potentially viable option for treating portal hypertension along with angiotensin-converting enzyme inhibitors (ACEI) (HEMSTREET 2004). $\mathrm{H}_{2} \mathrm{~S}$ regulates perfusion pressure in normal and cirrhotic liver in a NO-independent manner; $\mathrm{NO}$ and $\mathrm{H}_{2} \mathrm{~S}$ are released by different cellular sources and their hemodynamic effects involve different cellular targets. $\mathrm{H}_{2} \mathrm{~S}$ generation in cirrhosis is decreased due to a reduced expression/activity of CSE in hepatic stellate cells (HSC) - one of the main sources of $\mathrm{H}_{2} \mathrm{~S}$ in the liver (FIORUCCI et al. 2005). In our previous studies a tissue specific ACEI ramipril also enhanced the $\mathrm{H}_{2} \mathrm{~S}$ tissue level in the liver, heart and kidney (WILIŃSKI et al. 2010; WILIŃSKI et al. 2008). In kidneys $\mathrm{H}_{2} \mathrm{~S}$ has been recognized as an important regulator of renal function affecting both vascular and tubular actions (XIA et al. 2009). Some studies with carvedilol demonstrate attenu- 
ated increases in albuminuria as well as reduction in cardiovascular events in chronic kidney disease patients with hypertension (BAKRIS et al. 2006). Carvedilol also protected against the renal mitochondrial toxicity induced by cisplatin and daunorubicin-induced cardiotoxicity and nephrotoxicity in rats (AROZAL et al. 2010; RODRIGUES et al. 2010).

$\mathrm{H}_{2} \mathrm{~S}$ acts as a neuromodulator as well as an intracellular messenger in the central nervous system. Its perturbed metabolism has been investigated in many neurological disorders including Alzheimer's disease (QU et al. 2008). Recently, carvedilol was found to improve neuronal transmission and attenuate brain oligomeric beta-amyloid content and cognitive deterioration in two mouse models of Alzheimer's disease (WANG et al. 2010). Analogically, non-steroidal anti-inflammatory drugs were also demonstrated to exert some anti-amyloidogenic effects and to affect $\mathrm{H}_{2} \mathrm{~S}$ biology (BILSKA et al. 2010; SREBRO et al. 2006).

In conclusion, carvedilol affects the $\mathrm{H}_{2} \mathrm{~S}$ tissue concentrations in mouse brain, heart, liver and kidney. The involvement of $\mathrm{H}_{2} \mathrm{~S}$ makes the biological action of carvedilol more complex and opens new fields for investigation for both of them in neurology, cardiology, hepatology and nephrology. Several biotechnology companies are already developing $\mathrm{H}_{2} \mathrm{~S}$-based therapeutic compounds, and there are ongoing clinical trials investigating the therapeutic potential of $\mathrm{H}_{2} \mathrm{~S}$ (PREDMORE \& LEFER 2010).

\section{References}

Afonso R. A., Patarrao R. S., Macedo M. P., CARMo M. M. 2006. Carvedilol's actions are largely mediated by endogenous nitric oxide. Rev. Port. Cardiol. 25: 911-917.

Arozal W., Watanabe K., Veeraveedu P. T., Ma M., THANDAVARAYAN R. A., SUKUMARAN V., SUZUKI K., KoDAMA M., AIZAWA Y. 2010. Protective effect of carvedilol on daunorubicin-induced cardiotoxicity and nephrotoxicity in rats. Toxicology 274: 18-26.

BAKRIS G. L., HART P., RITZ E. 2006. Beta blockers in the management of chronic kidney disease. Kidney Int. 70: 1905-1913.

BELLENGER N. G., RAJAPPAN K., RAHMAN S. L., LAHIRI A., Raval U., Webster J., Murray G. D., Coats A. J., CLELAND J. G., PENNELL D. J. 2004. Effects of carvedilol on left ventricular remodelling in chronic stable heart failure: a cardiovascular magnetic resonance study. Heart 90: 760-764.

BILSKA A., ICIEK M., KWIECIEŃ I., KANIECKI K., PALIBOREK M., SOMOGYI E., PIOTROWSKA J., WILIŃSKI B., GÓRALSKA M., SREBRO Z., WŁODEK L. 2010. Effects of aspirin on the levels of hydrogen sulfide and sulfane sulfur in mouse tissues. Pharmacol. Rep. 62: 304-310.

Chakraborty S., ShuKla D., Mishra B., Singh S. 2010. Clinical updates on carvedilol: a first choice beta-blocker in the treatment of cardiovascular diseases. Expert. Opin. Drug Metab. Toxicol. 6: 237-250.

DAWN B., BOLLI R. 2002. Role of nitric oxide in myocardial preconditioning. Ann. N. Y. Acad. Sci. 962: 18-41.

Elrod J. W., CAlvert J. W., MORRISON J., DOEller J. E., KRAUS D. W., TAO L., JiaO X., SCALIA R., KISS L., SZABO C., Kimura H., CHOW C. W., LEFER D. J. 2007. Hydrogen sul- fide attenuates myocardial ischemia-reperfusion injury by preservation of mitochondrial function. Proc. Natl. Acad. Sci. U.S.A. 104: 15560-15565.

FioruCCI S., ANTONELli E., MENCARELli A., ORLANDI S., RENGa B., Rizzo G., DistrutTI E., ShaH V., MORElli A. 2005. The third gas: H2S regulates perfusion pressure in both the isolated and perfused normal rat liver and in cirrhosis. Hepatology 42: 539-548.

Fiorucci S., Distrutti E., Cirino G., Wallace J. L. 2006. The emerging roles of hydrogen sulfide in the gastrointestinal tract and liver. Gastroenterology 131: 259-271.

HEMSTREET B. A. 2004. Evaluation of carvedilol for the treatment of portal hypertension. Pharmacotherapy 24: 94-104.

ISHIGAMI M., HIRAKI K., UMEMURA K., OGASAWARA Y., ISHII K., KIMURA H. 2009. A source of hydrogen sulfide and a mechanism of its release in the brain. Antioxid. Redox. Signal 11: 205-214.

KALINOWSKI L., DOBRUCKI L. W., SZCZEPAŃSKA-KONKEL M., JANKOWSKI M., MARTYNIEC L., ANGIELSKI S., MALIŃSKI T. 2003. Third-generation beta-blockers stimulate nitric oxide release from endothelial cells through ATP efflux: a novel mechanism for antihypertensive action. Circulation 107: 2747-2752.

KOSTKA-JEZIERNY K., TYKARSKI A. 2009. Carvedilol. The library of the Arterial Hypertension - Journal of the Polish society of Hypertension. 1. Gdańsk, Via Medica. 1-50. (In Polish).

Li L., HSU A., MOORE P. K. 2009. Actions and interactions of nitric oxide, carbon monoxide and hydrogen sulphide in the cardiovascular system and in inflammation - a tale of three gases! Pharmacol. Ther. 123: 386-400.

OH G. S., PAE H. O., LeE B. S., KiM B. N., KiM J. M., KiM H. R., JEON S. B., JEON W. K., CHAE H. J., CHUNG H. T. 2006. Hydrogen sulfide inhibits nitric oxide production and nuclear factor-kappaB via heme oxygenase-1 expression in RAW264.7 macrophages stimulated with lipopolysaccharide. Free Radic. Biol. Med. 41: 106-119.

ŁOWICKA E., BEŁTOWSKI J. 2007. Hydrogen sulfide (H2S) the third gas of interest for pharmacologists. Pharmacol. Rep. 59: 4-24.

PREDMORE B. L., LEFER D. J. 2010. Development of hydrogen sulfide-based therapeutics for cardiovascular disease. J. Cardiovasc. Transl. Res. 3: 487-498.

Qu K., LeE S. W., BiAn J. S., Low C. M., WONG P. T. 2008. Hydrogen sulfide: neurochemistry and neurobiology. Neurochem. Int. 52: 155-165.

Rodrigues M. A., Rodrigues J. L., Martins N. M., BARBosa F., CURTI C., SANTOS N. A., SANTOS A. C. 2010. Carvedilol protects against the renal mitochondrial toxicity induced by cisplatin in rats. Mitochondrion 10: 46-53.

Romeo F., Li D., SHI M., MeHTA J. L. 2000. Carvedilol prevents epinephrine-induced apoptosis in human coronary artery endothelial cells: modulation of Fas/Fas ligand and caspase-3 pathway. Cardiovasc. Res. 45: 788-794.

RUFFOLO R. R., Jr., BOYLE D. A., VENUTI R. P., LuKas M. A. 1993. Preclinical and clinical pharmacology of carvedilol. J. Hum. Hypertens. 7 Suppl 1: S2-15.

Sen U., Basu P., Abe O. A., Givvimani S., Tyagi N., Metreveli N., Shah K. S., PAssmore J. C., Tyagi S. C. 2009. Hydrogen sulfide ameliorates hyperhomocysteinemia-associated chronic renal failure. Am. J. Physiol. Renal. Physiol. 297: F410-419.

Shibuya N., TANaKa M., Yoshida M., Ogasawara Y., TOGAWA T., ISHII K., KIMURA H. 2009. 3-Mercaptopyruvate sulfurtransferase produces hydrogen sulfide and bound sulfane sulfur in the brain. Antioxid. Redox. Signal. 11: 703-714.

SIEGEL L. M. 1965. A Direct Microdetermination for Sulfide. Anal. Biochem. 11: 126-132.

Sodha N. R., Clements R. T., FENG J., LiU Y., BiAnChi C., Horvath E. M., Szabo C., Stahl G. L., Sellke F. W. 2009. Hydrogen sulfide therapy attenuates the inflammatory response in a porcine model of myocardial ischemia/reperfusion injury. J. Thorac. Cardiovasc. Surg. 138: 977-984. 
SOMOGYI E., PIOTROWSKA J., RZESZUTKO W. 2008. An effect of some parameters of the determination of the hydrogen sulfide in pig liver and brain on the obtained results. Farm. Prz. Nauk. 5: 33-36. (In Polish with English summary).

SREBro Z., SOMOGYI E., WiLIŃSKI B., GÓRALSKA M., WILIŃSKI J., SURA P. 2006. Aspirin augments the concentration of endogenous hydrogen sulfide in mouse brain and liver. Folia Med. Cracov. 47: 87-91.

SUN Y. G., CAO Y. X., WANG W. W., MA S. F., YAO T., ZHU Y. C. 2008. Hydrogen sulphide is an inhibitor of L-type calcium channels and mechanical contraction in rat cardiomyocytes. Cardiovasc. Res. 79: 632-641.

Wang J., OnO K., Dickstein D. L., ARrieta-CruZ I., ZHAO W., Qian X., LAMParello A., Subnani R., FerRuzZi M., PAVlides C., Ho L., HoF P. R., TePlow D. B.,
PASinEtTi G. M. 2010. Carvedilol as a potential novel agent for the treatment of Alzheimer's disease. Neurobiol. Aging., doi:10.1016/j.neurobiolaging.2010.05.004. Published online July 1 .

Wiliński B., WilińsKi J., SOMOgYi E., Góralska M., PIOTROWSKA J. 2010. Ramipril affects hydrogen sulfide generation in mouse liver and kidney. Folia Biol. (Kraków) 58: $177-180$.

Wiliński J., SOMOGYI E., GÓRALSKA M., WiLiński B., CZARNECKA D. 2008. Ramipril enhances the endogenous hydrogen sulfide tissue concentration in mouse heart and brain. Folia Med. Cracov. 3-4: 123-130.

XiA M., CHEN L., MuH R. W., Li P. L., Li N. 2009. Production and actions of hydrogen sulfide, a novel gaseous bioactive substance, in the kidneys. J. Pharmacol. Exp. Ther. 329: 1056-1062. 